ARTICLE

\title{
Left Out: Notes on Absence, Nothingness and the Black Prisoner Theorist
}

\author{
Taija McDougall \\ University of California, Irvine, US \\ tmcdouga@uci.edu
}

\begin{abstract}
Despite his incarceration in 1961 on a one-year-to-life sentence, George Jackson was a prolific Marxist theorist, with two books published. His autobiographical epistolary text Soledad Brother, published the year before his death in 1971, contains letters to family, friends, and supporters that are at once deeply personal and broadly theoretical. These letters consider and analyze the ways that he finds himself (re)captured and thus caught in the machinery of the US- American carceral apparatus. Jackson's theory of revolutionary politics, linked to American and global struggles against imperialism, was of particular interest to Gilles Deleuze, whose conceptualization of the Line of Flight is furnished by a crucial quotation of Jackson's: "I may run, but all the time that I am, I'll be looking for a stick" (328). This quotation from Soledad Brother, with minor variations, winds through Deleuze's collaborative oeuvre, from Anti-Oedipus with Felix Guattari to Dialogues II with Claire Parnet, and forms a key aspect of the notion of the line of flight, which has been further mobilized by recent scholars. Despite the importance of this quotation, it goes uncited throughout all of Deleuze's work, in all editions, in multiple languages, in both print and digital mediums. There is no included bibliographic information and no editor's note or translator's note as to why this is the case. The reference is simply absent, with its most glaring absence in the bibliography of Anti-Oedipus. Using this absence as a point of departure this paper will consider Jackson, and by extension Black/Prisoner beings, as disavowed theoreticians, whose contributions cannot be considered. Further, I argue that this 'leaving out' is a critical aspect of both prisoner status and its linkage to Blackness, reflected in the ways that Jackson is bound to both (non)positions. In hope of maintaining the integrity of the absence in Anti-Oedipus, this paper will further interrogate the meaning of such an absence, and the parasitic relation of something to nothing and the uncitability of Black prisoner as theorist.
\end{abstract}

Keywords: George Jackson; Gilles Deleuze; Anti-Oedipus; Line of Flight; Black Studies; Absence/Presence

Hang on, I'm going to make everything all right. -George Jackson ${ }^{1}$

Attempting to narrate an absence produces accompanying complications that expose the paradox around the split between presence and absence. How does one think an absented thing, which suggests that both the presence of the thing must be affirmed in order to then recognize that the thing is not there? Put otherwise, one is immediately called upon to discern a way to write a thing's lack, the blank, empty space into being, only to negate that being again in recognizing this non-it as absent. Moreover, to move beyond thinking an absence, how can we systematize or categorize varieties of nothingness? Should we? To go further, how does the absented thing puncture, mutate and deform the systems from which its absence is noticed? We could call the absented thing ghostly, but this suggests a minimal materiality that does not

\footnotetext{
${ }^{1}$ George Jackson. Soledad Brother: The Prison Letters of George Jackson. Lawrence Hill Books, 1994, p. 39.
} 
grasp the sheer weight (or lack thereof) of what absence ultimately implies. With these questions animating my thinking, what do we do with an absented theorist in a bibliographic record? What kinds of lines can we follow when we are faced with the nothingness of a missing citation in a theoretical work? What, then, do we make of this problem when Blackness and the carceral technologies of reconstituted enslavement work together to produce a blank space where there should exist a citational record of the work of the theorist?

While working on another project about Black revolutionary theorist George Jackson, I found myself confronted by an absence in the bibliography of Gilles Deleuze \& Felix Guattari's Anti-Oedipus. Within the fourth chapter of Anti-Oedipus, "An Introduction to Schizophrenia," like in many other places in Gilles Deleuze's work in proximity to his time with the Prison Information Group, he mobilizes a quote from Jackson's collection of letters, Soledad Brother. This quote, always accompanied by Jackson's name, is used multiple times all in conjunction with the notion of the line of flight, one of Deleuze's key concepts. The key passage of Anti-Oedipus reads:

I am not your kind, I belong eternally to the inferior race, I am a beast, a black. Good people say that we must not flee, that to escape is not good, that it isn't effective, and that one must work for reforms. But the revolutionary knows that escape is revolutionary-withdrawal, freaks-provided one sweeps away the social cover on leaving, or causes a piece of the system to get lost in the shuffle. What matters is to break through the wall, even if one has to become black like John Brown. George Jackson. 'I may take flight, but all the while I am fleeing, I will be looking for a weapon'5 (Deleuze \& Guatarri 277).

Included in the above quotation is the superscript 5 , to indicate the reference in the endnotes. When one flips to this reference, there is nothing there. In the English translation, there is a blank space that has been opened up between a translator's note and a reference for Allen Ginsberg's Kaddish, but there is no bibliographic information for Jackson. There is only absence, blankness, emptiness and the attendant problem of how to read and understand this lacuna in the citational record. ${ }^{2}$

Rather than attempting to fill in this absence, in what follows, I am more concerned with tracing the contours of Jackson's missing citation up to and including the blank space produced on the page itself. Three general trajectories will form the spine of these notes. Firstly, what is this blank space? How did it get there and how can we understand it as related to citational politics and practice? Secondly, in thinking Blackness, incarceration and nothingness together, what effects does this absence produce? Then, taking the absence itself seriously with the ways it relates to Blackness, incarceration and nothingness, we can turn to the notion of escape when viewing Jackson as always already outside that which Deleuze and Guattari suggest can be escaped, deforming and deranging the line of flight for a Blackness constituted by absence. Furthermore, instead of proceeding linearly, this is a collection of notes and considerations, which move and flow together, producing overlaps, reorganizations and reconsideration.

\section{Around the Edge}

What possible reasons could there be to find a blank space where there should be a citation in this foundational and fundamental poststructuralist text? I identify three possible explanations. Firstly, the omission could be an actual oversight, a mistake that has actually gone unnoticed and thus uncorrected for over forty years. The second possibility is a deliberate performative gesture on the part of Deleuze and Guattari, signalling something about Jackson, considering their own declaration of a revolutionary politics is to somehow "become black like John Brown" (277), the insurrectionist abolitionist. The third conceivable explanation is disavowal, whether conscious or unconscious. It is the least charitable option, but in moving through the first two possible explanations, it is apparent that disavowal underwrites the other two possibilities.

Both of the first two possibilities have important implications beyond the textual world of Anti-Oedipus and it is in these implications that they lead to disavowal as the explanation we should accept. Contending first with the notion of the omission of Jackson being a mistake, it presents an immediate problem for people beyond Deleuze and Guattari. This explanation would implicate not only the collaborative authors for a failure of acceptable citational practice, but also their English publishers, their English editors and translators. Moreover, this would be a mistake that has been reproduced, textually and materially since 1977,

\footnotetext{
${ }^{2}$ In her 2010 dissertation, Michelle Koerner notes this missing citation, noting that it is one of "two curious details." While the problem of this citation is mentioned in her work, Koerner does not attempt to theorize this absence.
} 
suggesting an immense failure of editing, proofreading and all the labor that goes into issuing translating new editions of academic works. But it devolves further, suggesting that this absence should not be understood as a mistake.

This omission, this absence, is reproduced elsewhere in Deleuze's oeuvre, though not in the glaring way that it is made paradoxically visible in Anti-Oedipus. Variations of the same quote go uncited in A Thousand Plateaus and Dialogues II with Claire Parnet. ${ }^{3}$ As Koerner notes, this singular quote, "Jackson's name-always accompanied by the refrain 'I may run, but all the time that I am, I'll be looking for a stick'" ("Lines of Escape" 160) is absent from the references in all three texts and the original French (1972) and the German translation of Anti-Oedipus (1974). ${ }^{4}$ Importantly, there is no space for the footnote reference to Jackson neither in the original French nor the German translation. A space was specifically opened up in the English translation for this reference, and yet none was provided.

A mistake would not explain why this particular citation does not appear in the French and the German versions of the text. Further, as noted above this particular quote is deployed elsewhere in Deleuze's collaborative work, each time translated slightly differently, and each time, requiring further labor surrounding this quote, as its deployment would be considered by Deleuze, and thus would have to be translated and was re-translated multiply. If this is a mistake, it is an easily correctible one; it is located in Soledad Brother in one of Jackson's letters to lawyer Fay Stender. Further, as Jackson's text was published in France in 1971, and this quote was used in the GIP's pamphlet Intolérable: L'assassinat de George Jackson, this could have been referenced in the French, even if no space exists for it in the published, committed-to-material book (GIP).

Perhaps it hasn't been noticed because it is not really an omission, but rather a performative gesture at Jackson as a figure, as "a beast, a black" (Deleuze \& Guattari 277) a revolutionary, a prisoner, and that which is always on the run, both deterritorialized and deterritorializing. An exhausting position to be sure. Perhaps the gap, the absence that exists in between a translator's note regarding Deleuze's own Différence et repetition and a reference for the section of Allen Ginsberg's Kaddish that is quoted two pages later, was done to indicate that Jackson, in his life under what Jared Sexton terms "the shadow of social death" (27) and subsequent death in captivity, could be thought to be a precisely the revolutionary they write of. Deleuze and Guattari write, "the revolutionary knows that escape is revolutionary-withdrawal, freaks-provided one sweeps away the social cover on leaving, or causes a piece of the system to get lost in the shuffle" (277). Jackson escaped, Deleuze and Guattari then imply. He blew off the social cover. However, the dragon entered the prison, but never exited. He was gunned down during what has been called an escape attempt by the San Quentin Prison, the state, and those committed to maintaining the legitimacy of both.

Here, I would like to return to the preceding translator's note, which suggests one turn to Différence et répétition for a more sustained treatment of concept of repetition by Deleuze. It is not the content of such a note that presses in, but rather the fact of translators' notes, that introduces a temporal framework that I contend detracts from the notion of a performative gesture at work in the omission of Jackson from the bibliographic record. The translation of "Introduction to Schizoanalysis," the crucial chapter was carried out by two of the three translators of the full book: Mark Seem, who also wrote one of two prefaces, and Robert Hurley. Two translators, who make suggestions of further reading, clarify certain references that the authors make in the text, and yet there is no translator's note to explain why there is this profound lack. In the original French, while there is no indication that there should or could be an accompanying footnote for the quote, there is no space, no absence. This is precisely the space for a translator's note or an editor's note to suggest that there is something else at work in this absence, that there is some reason for this omission.

When we consider the possibility of performance against the first of these two peculiarities details there is disavowal, either on the part of Deleuze, on the part of the translators, or everyone. Koerner writes regarding this always-mistranslated quote that we have to ask, "how did it happen that an American writer, a black American writer, is so unrecognizable to Deleuze's English translators that he is repeatedly mis-translated?" (143). I would add to this, how is it possible, alongside these constant mistranslations, that there is then no reference for Jackson in any of their three texts, particularly in Anti-Oedipus where a space has been specifically opened up during the process of translation and editing, without this being disavowal? Taken together, these two curious details about Jackson in Deleuze together, the mistranslations and the omission from the

\footnotetext{
${ }^{3}$ See Gilles Deleuze and Félix Guattari, A Thousand Plateaus: Capitalism and Schizophrenia. Translated by Brian Massumi, U of Minnesota Press, p. 204; Gilles Deleuze and Claire Parnet, Dialogues II. Translated by Hugh Tomlinson and Barbara Hammerjam 2007, Columbia UP, 2007, p. 36.

${ }^{4}$ See Gilles Deleuze and Félix Guattari, Capitalisme et Schizophrenie l'Anti-CEdipe. Les Éditions de Minuit, 1977; Anti-Ödipus: Kapitalismus und Schizophrenie I. Translated by Bernd Schwibs, Suhrkamp, 1974.
} 
citational record in Deleuze's work do not indicate a performance of exclusion, or of failed representation. At work, there is a denial, a disavowal of something about Jackson or his text that is intolerable and, thereby, uncitable.

We can thus take all of the above together. A mistake, while certainly possible, could have been caught and rectified since the 1972 French publication and the 1977 English translation and its 1983 reissue with University of Minnesota Press, then its move to Penguin Classics in 2009. With every edition come opportunities to fill in the gap. Further, because neither the gap nor the citation appear in the original French, a space was specifically opened up in order for something, be it the citation itself or a translator's note. We could call it a correction of a correction, thus a disavowal in which a structure suddenly makes itself known. To term this omission a mistake does not appear to address the problem of this absence. Were it to be a performative gesture with an intended purpose by Deleuze and Guattari, it would appear in the French and the translated German as the same gap as in the English translations. Instead, in the original, there is no citation whatsoever and in the translated English a space has been created. In the opening up of the number five reference with all indications suggesting it should be for George Jackson and then leaving it wholly blank, the interaction between Blackness, incarceration and nothingness comes to the fore.

\section{What lives there}

If we take disavowal as the driving force behind blank space of the English translation of Anti-Oedipus, what then is being disavowed? What drives are at work that render Jackson uncitable within the French original, but moreover, open a space and make the absence of Jackson material. The gap on the page transforms an uncited reference to a lacuna, a space of/for nothingness. In attempting to keep the absence of Jackson in the citations for Deleuze and Guattari's text, what is it that did not and could not fill that space? I contend that this is a conjoined set of disavowals: both of Jackson as Black and Jackson's theorizations of capture as perpetual and thus constitutive for Blackness. Jackson exists pressed under the weight of Blackness and Blackness as capture, concepts that form the scaffolding of Deleuze and Guattari's conception of a revolutionary praxis. His existence is crowded out when it comes to official record of his influence, opened up to the possibility and then left tellingly blank. The conjoined disavowals that I suggest animate the blank space in Anti-Oedipus have further implications for the ways in which Jackson is used in the text and the ways Deleuze and Guattari deploy and mobilize their version of Blackness and an attendant notion of capture that leave us on the doorstep of nothingness as a critical to both Blackness and incarceration.

For Deleuze, Blackness is something someone can become, like John Brown. There is some way to Blacken oneself when one does as Deleuze and Guattari suggest is revolutionary: escape while constantly mounting a counterattack. One can drop out and then/thus become Black. But what of those whose (non)position places them outside from birth, for whom escape could be attempted, only to find out that they are already outside the world? Jackson excavates something different, that he cannot escape throughout Soledad Brother. Despite the concern with escape/counterattack that runs through the text, he finds that his "recall is nearly perfect, time has faded nothing. I recall the very first kidnap. I've lived through the passage, died on the passage, lain in the unmarked shallow graves of the millions who fertilized the Amerikan [sic] soil with their corpses, cotton and corn growing out of my chest" (Jackson 234). It may "pain [Jackson] to dwell on the past" (234) but the past, that half millennium that they've been "'killing all the niggers'" dwells upon him, inscribed directly into his flesh and thus seared into his mind (234). Blackness is the means of escape, for Deleuze and Guattari, but for Jackson it is that which cannot be escaped.

The "schema of captivity" (51), to borrow a useful phrase from Dionne Brand, winds its way through Jackson's text. Jackson is a theorist, in and through his loosely termed 'autobiography' and his letters, which address both their intended reader, and via publication, a radical audience, of which Deleuze and Guattari appear as part. Jean Genet writes in the introduction of Soledad Brother that it is a "striking narrative of love and combat" none of which "has been willed, written or composed for the sake of a book" (Genet 332). Yet, it is a book, meaning it exists within the various matrices of meaning that we grant books, autobiography, prisoners, Jackson himself, left politics, revolution, and in the infrastructural, Blackness. As a book, Soledad Brother both adheres to and obfuscates the autobiographical category, an undertaking I contend is performed in all forms of Black life writing. His narration and theorization intercommunicate as he works through capture as not only the state that he finds himself in, but also as that which forms Blackness as an ontological (non)position.

Jackson's text is theory in that while he develops notions of escape, revolt, counterattack, fascism, imprisonment and enslavement, he inadvertently theorizes his own Blackness. It breaks through the structure of his letters, and the ways that he considers himself as imprisoned. While he claims that he "can't be satisfied with himself until [he is] communist man, revolutionary man" (emphasis Jackson's), still thinks of himself 
as "black, and an African" (Jackson 308). Jackson cannot escape the weight of Blackness that presses in, breaks through the theorizing of Marxism, revolution, and carcerality. Soledad Brother labors to suggest escape/counterattack as the posture of resistance, of revolution, but 'scenes of subjection' break through the wall before he can. His "mind ranges back and forth through the uncounted generations, and I feel all that they ever felt, but double" unable to actually escape the unbearable Blackness (234). The enemy for Jackson is total, it "cannot be appeased, ... he is relentless, calloused beyond repair, dedicated to personal financial success, heedless to its cost in human suffering" (178-9). Scenes of the gratuitous violence of enslavement and its atemporality break in upon Jackson, culminating in the final entry in the text after the death of his brother at the Marin County Courthouse.

For Jackson, despite his attempts to escape his incarceration, he constantly finds himself as the object of the technologies of capture. He takes on a hopeful tone as he writes that "[t]ime is on my side. I'm twenty-six now, and I'll be twenty-six when I leave here. Be it 40 years from now" (139). He is noting a nonpassage of time, and a foray into an examination of nothingness that underlies and underwrites Blackness, capture/incarceration and is made paradoxically visible in the references of Anti-Oedipus. These nods towards a static temporality run through Soledad Brother; time refuses to be ordered in the standard ways in the text despite it being a dated collection of letters. This agitated temporality, I argue is joined up with incarceration and Blackness that is so critical to Jackson's life and Deleuze and Guattari's use of the former and their formulations of the line of flight. When we take this confluence of Jackson's self-reflexive theorizations, Deleuze and Guattari's use of Jackson's theorizations, and the paradoxically included absence of the latter theorists citation, we are left with a series of instances that point us in the direction of a problematic of nothingness is what joins these three together. Put differently, nothingness, blankness, lies at the heart of Jackson's prison narrative, and in serving as theoretical scaffolding for Deleuze and Guattari's line of flight, this nothingness is reflected in their inability to bring Jackson into the fold of the bibliographic record.

Contending that there is nothingness and absence at the heart of these interconnected projects should not be understood as there being negation at the heart of these projects. Negation would require a presence that I argue does not and cannot exist for Jackson. Rather, I claim that Jackson spends the loose narrative of his collected letters ruminating on the meaning of an enforced nothingness. As he writes that he is the "most resilient dead man in the universe" (234) he hints at this split between negation and nothingness. Jackson is not a corpse or a thing, but a dead man; he is a man made into nothingness. He is a man that died "as most of us blacks have died over the last few centuries, without having lived" (146). This is suspension between death and life, this no-place, no-event that is illustrative of the prisoner generally, but of Jackson specifically as he theorizes the time between capture and escape. It is a nothingness that is made unintentionally visible in Deleuze and Guattari's book.

\section{Holding onto Nothingness}

With the remaining space, I want to the hold up some of the aspects of nothingness as bound up with this missing citation. I want to pay specific attention to the ways that nothingness can be enforced, and then the contrast between nothingness and non-relation and non-position. These granular distinctions are critical to any excavation of a gap like we find in the reference of Anti-Oedipus. Other gaps like this perhaps may not be so clear, so when we find the evidence of them, rather than aiming to immediately fill the gap and negate the nothingness, there are other avenues to explore. We can and should continue to develop a practice of holding nothingness, sitting in the paradox itself.

Enforcement of nothingness yet again presents us uncomfortable theoretical terrain. This nothingness, firstly, is distinct from the nothing in the question 'why is there something rather than nothing?' Yet, this question spurs on its inverse: 'why is there nothing rather than something?' This nothingness made visible in the references of Anti-Oedipus should be conceived of as an instant, an opening into both possibility and impossibility where something should be but is not. We could envision this nothingness as a bounded and bracketed omission and a void that could pull everything into its orbit. Omission in the case of the nothingness found in Deleuze and Guattari's book is key; it is where something could have been, but is not. Moreover, it is where something should have been but is not.

Omission in this case can and should be understood as concomitant with the violence of anti-blackness. The opening of a space for an omission to then occur, a rendering into blankness, is not the opening of multiple possibilities for integration into the structure, practice and politics of citation, but rather as nothingness, a strange echo of partus sequiter ventrem. The blank space strangely visible in the text is not an erasure, which would suggest there was something there before that had been removed, blotted out, papered over or scrubbed away. Instead we might view the blankness, the nothingness as an irresistible vacuum, a black hole. It presents us with a peculiar puncture in the fabric of thought, which could pull everything into its 
orbit, which could deform everything around its edges. These edges around the nothingness of the missing citation, the nothingness that Jackson is considered if we follow the logic of even an unconscious disavowal of his work.

On the side of enforcement, the bounding and bracketing are the limits of the anti-black world that press in upon what it perceives as nothing. According to the structures and strictures of liberal humanism, the being Jackson should be present, but we are faced with a situation in which this being is not. The prisoner Jackson should be present, but is not, even in their documentation. Thus, the theorist Jackson should be present, but is not. His status as a nothing in the gaze of the world, a criminal in the gaze of the prison, is held this way. Attempts to be brought into the world, into the human fold, into the world outside the prison, fail repeatedly. The various discursive apparatuses that Jackson comes up against in his text, such as the parole board, enforce his nothingness, just as the gap present in Anti-Oedipus enforces his nothingness in the sense of the theoretical world.

Connected to these problems of the enforced nothingness of the Black figure, the incarcerated figure, and the blank space where Jackson should be is the problem posed by Foucault's claim that the prisoner is reduced to his paperwork. He writes that those caught within the carceral network are transformed into a case, a collection of documentation from parole applications, incident reports, evidence log sheets, what Foucault terms a "network of writing ... a whole mass of documents that capture and fix them" (Foucault 189). Once again, to take this claim when faced with the situation of Jackson's omission from Deleuze and Guattari's text, questions and problems posed by their answers teem to the surface.

Just like carceral writing and documentation, systems of citational practice do work to capture and fix not only those subjects deemed worthy of authority, but also capture and fix the logic of the practice itself. Circulation and re-circulation are granted to those deemed to have the authority to midwife the reproduction of worlds around certain, specific bodies, pace Sara Ahmed. This should be extended further to reproducing the world around those whose bodies can be reduced to flesh, following Spillers, with that constant violent possibility of being reduced to documentation (64-81). Jackson's omission and subsequent rendering into nothingness in the citational record of Anti-Oedipus comes into ironic confrontation with the network of writing. The disciplinary and control surveillance of the world, of which the carceral network and systems of citation are part, should afford Jackson documentation within the assemblage of structures, up to and including Anti-Oedipus. And yet, the absence remains. The bracketed and bounded space where ostensibly a node of the network of writing that would constitute Jackson as an object of the carceral gaze remains empty. Of course, other documents exist for Jackson, but he cannot be reduced to them.

The gap that opens when a document has gone missing or, in the specific case of Jackson, has been omitted and transformed into nothingness, suggests a problems for the applicability of Foucault's claim. If a prisoner in the carceral apparatus is nothing but their documentation and they are simultaneously denied documentation, we are left in a dilemma which suggests the prisoner is both nothing but documentation and undocumentable. In this dilemma, the Black prisoner is suspended in the network of carceral writing and runs up against the absence of Jackson in network of writing that attempts to run counter to the carceral system. The nothingness that accompanies the space that was generated for something to do with Jackson in Deleuze and Guattari's text implicates the brackets and borders that demarcate the boundaries of the nothingness. In the case of the references of Anti-Oedipus, citations 4 and 6 limit the space of the blank 5. This situation suggests Jackson is in a situation of non-relation; he and his theorizations are not related to the world of Deleuze's other work or Allen Ginsberg's poetry that surrounds him. Jackson comes unstuck from Frantz Fanon, who is cited on page 96 of Deleuze \& Guattari's text. He is made unrelated to all the others who can be brought into the gaze of fixture of citational practice and gaze of capture of the carceral space.

Jackson's non-relation in and through this nothingness becomes exemplified in Deleuze and Guattari's text. In the space that is opened, be it by editors, translators, or Deleuze and Guattari themselves, and its attendant emptiness, Jackson's theorizations can make their way into the text, even if it is as not much more than sloganeering, but in not being citable, Jackson's nothingness comes with a side of non-relationality. He is outside not only the world via what he terms neoslavery in and through the prison, but he is outside the world of institutional and academic practice. His theorizations are unmoored, unfixed, unstable and so unrelated to those that surround him. More than this, they cannot be moored, fixed, or stabilized.

On this unstable terrain, Jackson cannot become another theorist whose work can be mobilized to support other lines of thinking. Instead his quote 'I may take flight, but all the while I am fleeing, I will be looking for a weapon,' accompanied by his name, becomes a slogan for Deleuze and Guatarri's project [Anti-Oedipus] and their theorizations of the line of flight, which I will take up again later on. This posture of escape/counterattack, which the French theorists imply is the revolutionary posture, allows Jackson to be nothing more 
than furniture in the thinking spaces of Anti-Oedipus and its concerns with the breaking through the walls of the system. Does Jackson break through the wall, both in his fatal 'escape attempt' and in his theorizing, taking a piece of the system with him? Or does the system crowd him out regardless of his desires, regardless of his investments? He stands in non-relation to these things, out of the social field via his Blackness first and foremost. Moreover, in the fully expressed state of capture in which he is situated, the social field shifts and moves around him, ensuring that he remains bracketed and bounded from it. While the prison, and its related institutions, exists within the social field, it is a machine that when brought into confrontation with the legacy of Transatlantic enslavement, does the labor of ensuring that Black life remains outside the social field. Put differently, the prison is the new and improved technology of enslavement; the penal institution is one of the factories that enforce the nothingness that is Black life. Jackson's omission is a micro-site of control, of a violence of silence, erasure and exclusion from the archive, from the system of citation, and from the schematic of accepted practices of thinking more generally. Thus, when we are asked to contend with Jackson as theorist, we are left with a paradoxical blankness, a lack from what serves as the official record, the archive of Deleuze and Guattari's thinking even as he is conjured in the text itself.

\section{Somethingness as Parasitic}

We are left in a position in which Jackson cannot be brought into the realm of thinking on account of the enforced nothingness that is betrayed and thus illuminated (obscured?) by his omission and banishment from the references of Anti-Oedipus. His is the enforced nothingness that Blackness and its bedfellow enslavement-more accurately its updated re-organized and re-invigorated form: the prison-are made to labor under. It would serve well here to examine what feeds off of such a situation. If we say that Jackson cannot be brought into the accepted theoretical structure of Deleuze and Guattari's text, yet they are able to deploy and mobilize the escape/counterattack strategy that Jackson writes and thinks, then we are left with a problem. Deleuze and Guattari take and give nothing back. Jackson gives and gets nothing in return, except to be called upon and then left for dead, and left to death.

The line of flight as a theory feeds off the body and mind of George Jackson and cannot bring him into the world (of the living) in and through the commonly accepted discourse forming and fixing practice of citation. In their eagerness to conjure Jackson as Field Marshall of the Black Panther Party, as imprisoned Black intellectual, Deleuze and Guattari and the entire publishing apparatus, which should have caught this omission, reveal the libidinal undercurrent of such a conjuring. They call Jackson forth to make a point, to underline, to demonstrate that Blackness is escape only to reject the captivity and suffering that is bound to the Black body that Jackson attempts to work through only to be unable to commit to the proof. They feed on Jackson's corpse, but neglect the wake (here, calling upon Christina Sharpe's crucial work). Jackson is made into an absence, a shadow figure that cannot be cited, cannot be indexed, only trotted out to disavow later, while simultaneously suggesting that one can take on this same Blackness. Deleuze and Guattari's theorizations become the complementary somethingness to the nothingness of Jackson and his theorizing.

Jackson being missing utterly from the text except in his bracketed and bounded locus in the prose of Anti-Oedipus, separated from John Brown and his own quote, rematerializes into a host. His nothingness is that which organizes the somethingness of Deleuze and Guattari's formulations, which in turn take on the role of parasite, of carrion-feeder. Feasting on the flesh of the dead Jackson, who is paradigmatically caught between the moment of capture and the moment of escape. Jackson lived and died. His escape attempt that culminated in his murder occurred the year before the publication of Anti-Oedipus in the original French.

This parasitism, in which Deleuze and Guattari's thinking feed off of the theoretical and material life of George Jackson, functions as a method of control of the unruly Black flesh that occupies a non-position and a non-relationality. Parasitism in this case allows for the endowing of theory without contending with the ways in which those unproblematically within the world rely on those who are banished, permanently disgraced. Put differently, those whose living and breathing are always already at risk of death and dying of banishment and abandonment, like Jackson, form the firmament upon which thought and the world are built, yet are made into nothing. It would appear I have introduced a contradiction to this reading of the gap in the Anti-Oedipus where Jackson could be but is not. If Jackson is in non-relation to the world, how could I then go on to claim that there is a parasite-host relation? I argue this is a continued case of non-relation. For the parasite, the host is the air they breathe, the food they eat, the invisible and unaccounted for accouterment of living, constituted by the host. The host is un-related to the parasite, except as that which holds the parasite's world in place; without the host the parasite ceases, but the host could go on without. The parasitism works because the hosts cannot notice that they are providing material life for the parasite and the theoretical ground on which the parasite finds itself. In a world of parasites, the host is a non-entity. 
The theoretical host Jackson is a non-entity for Deleuze and Guattari's text; the line of flight is a parasitical theorization of Jackson's escape/counterattack posture.

This is the shadow-world of non-relation: the parasite-host non-relation, generating an enforced nothingness for the host and the life-granting somethingness for the parasite. I would claim that aspects of Blackness work the same way, and the sub-field of Blackness as a part of the reconstituted plantation, folds into this logic.

In order to "become Black like John Brown" (277) in the words of Deleuze and Guattari, George Jackson, who is Black without any becoming required, must be cast as different from the insurrectionist abolitionist. George Jackson's nothingness, which we find in the references, allows the somethingness of John Brown to be illuminated and underscored. The somethingness of the theory that Deleuze and Guattari call the line of flight has within it, but held fatally separate, the nothingness of he who lived and theorized, caught and suspended in the vibrations between capture and escape. Despite their attempts, this Jackson, the actually existing Jackson, the one that writes, "I may run, but all the time that I am, I'll be looking for a stick!" cannot be rendered thinkable by the structures of discourse in terms of citation. His escape/counterattack posture is taken up by Deleuze and Guattari, and mentioned in the same breath as John Brown who, according to the French theorists, Blackened himself, but John Brown and Jackson are kept distinct. John Brown chose to escape; Jackson is suspended in that which brackets him, suspended in the world, but never a part of it.

Deleuze and Guattari, in their use of Jackson's quote without citation and indexation, relate parasitically to Jackson and to Blackness generally as they argue that one can break through the walls of the world to become Black. This is the line of flight and it is built directly over the corpse of Jackson, the theorizing of himself as a thing who will be held fatally still, even as he considers capture, escape and counterattack. Blackness is inescapable for those who do not so much become Black as are born, live, and die as Black. In formulating the line of flight as linked to Blackness, and its own perpetual escape, they feed off of the captivity of Jackson while never contending with the notion that captivity is the schema within which Jackson must always already be operating. In order to be, as Deleuze and Guattari see it, revolutionary, one must Blacken themselves, escape to that outside, where "cotton and corn grow out of the chests" (Jackson 233) of all those commodities that crossed the Middle Passage, those of which Jackson is one. They must breach the divide that cannot be breached by its nature. One cannot make a choice to become a body that "magnetizes bullets" (Wilderson 77); one either is that body, or it is deputized to use those selfsame bullets. Jackson cannot, and does not escape, no matter his desire. His enslavement, and thus absence from social, civil, and citational life, extends through time, beyond his physical death, beyond his birth.

These seemingly unconscious theorizations of Blackness in Soledad Brother are what cannot be thought by Deleuze and Guattari and thus cannot be brought into the discursive activity. This is what the absence in Deleuze's work suggests: while the fruitful and useful aspects of Jackson's work can be used, his own Blackness precludes him from citation. While Jackson writes, "I don't mind dying but l'd like to have the opportunity to fight back," he also writes of being born with a terminal cancer ... It has robbed [him] of these twenty-eight years. It has robbed us all for nearly half a millennium," Blackness is the interstitial theorization that occurs between the others, writing further that he is "tortured by the vision of someone like [himself] standing at the bars of his cell two hundred years from now" (211). Jackson's theorizations of the escape/counterattack posture are perpetually broken in upon by their own failures. Here, Jackson recognizes what Deleuze and Guattari do not, and thus disavow: that Blackness as formed by the gaze of the world is infinitely suspended, inescapable, permanent, and cannot be taken up by the schizorevolutionary, the insurrectionist, and so on.

In light of this absence, what then of Foucault's notion that the prisoner is that which can be reduced to documentation when thought together with this absence? Prisoners are caught in a complex of writing, from the records of the individual case, extending to legal theory, criminology case studies, bills of rights, and so on. Does the Black being Jackson, who's Blackness cannot be thought by Deleuze, who mobilizes him so frequently, deform the notion of documentation as constitutive of the prisoner in the modern prison. Can the documentation which terms Jackson "brigand, thief, burglar, gambler, hobo, drug addict, gunman, escape artist, Communist revolutionary, and murder" (4) be what he is? While Doran Larson writes that the prison writer writes against and resists the regime that is documentary, in the case of Jackson, the documentary function of the world outside the prison refuses to document him. Rather than only uncited, he is uncitable. The theory of the line of flight can be thought with Jackson, but when the fact of his Blackness attempts to enter the frame that Deleuze and Guattari construct for it, Blackness slips away, and becomes a chosen posture rather than a constitutive element of the logic of capitalism and of civil society. 
In his introduction to Serge Livrozet's De la Prison à la révolte, Foucault critiques the habit of taking up prisoners' stories about themselves, while leaving their theorizations to the side. With Jackson's quote, deployed in Anti-Oedipus, A Thousand Plateaus, and Dialogues II, Deleuze and his collaborators do the opposite. He takes on Jackson the theoretician and leaves to the side Jackson the Black being and what Jackson theorizes about as tied to his imprisonment and continued enslavement. This unthought and unthinkable aspect of Blackness is that which can never be taken on and worn, as Deleuze and Guattari suggest is the activity of the revolutionary, and it cannot be documented outside of those prison letters. Jackson's blackness cannot enter into the official record for Deleuze and Guattari. They can mobilize his theorization of escape/counterattack, cannot commit to the scholastic and bibliographic record Jackson's text, in which there is a failure of the ability to escape and counterattack. It must then be disavowed. A space can be opened for it, as is the case with the English translations omission, but Jackson can only exist between the records, between the words of that which can be countenanced by Deleuze's project, the translators, and the world within which they operate.

Absence, nothingness and non-relation via the parasite/host connection infest the death and life of the Black prisoner. With the introduction of the theorist as a dimension, as in the case of George Jackson, whatever he produces at the moment it is brought into the discursive world of prose, it is also disavowed. It cannot be understood through the usual structures and apparatuses that make theoretical practices legible and intelligible; rather he is left out. He cannot be brought back in. With this comes the problem of how one thinks, narrates, or reaches into an absence in the face of the sheer nothingness that appears in the citational record of Anti-Oedipus. The point with the above notes has not been to fill in the absence or the nothingness, but rather to sit with the nothingness that the world leaves us. While the epigraph/epitaph that opens this collection of musing suggests that if we hold on, Jackson is going to make everything all right, 'all right' here does not entail that we fill in the gap that is left. Making everything all right, and the revolutionary energy that this requires, is not introducing him into the citational record. Committing Jackson to documentation is not the way forward. Rather, sitting with the problem of absence, recognizing the teeming, overlapping, and troubling meanings of nothingness and the violence that an enforced nothingness affirms does some of the labor. In the final instance, specific movements in the nothingness that Jackson represents is what we have, not only for Deleuze and Guattari, but also for the world that Blackness holds in place.

\section{Competing Interests}

The author has no competing interests to declare.

\section{References}

Ahmed, Sara. "Making Feminist Points." Feminist Killsjoys blog, 2013, feministkilljoys.com/2013/09/11/ making-feminist-points/. Accessed.

Brand, Dionne. A Map to the Door of No Return: Notes on Belonging. Canada: Vintage, 2001.

Deleuze, Gilles and Claire Parnet. Dialogues II. Translated by Hugh Tomlinson and Barbara Hammerjam, Columbia UP, 2007.

Deleuze, Gilles and Félix Guattari. A Thousand Plateaus: Capitalism and Schizophrenia. Translated by Brian Massumi, U of Minnesota Press, 1987.

Deleuze, Gilles and Félix Guattari. Anti-Ödipus: Kapitalismus und Schizophrenie I. Translated by Bernd Schwibs, Suhrkamp, 1974.

Deleuze, Gilles and Félix Guattari. Anti-Oedipus: Capitalism and Schizophrenia. Translated by Mark Seem and Robert Hurley, U of Minnesota Press, 1983.

Deleuze, Gilles and Félix Guattari. Capitalisme et Schizophrenie l'Anti-CEdipe. Les Éditions de Minuit, 1977.

Foucault, Michel. Discipline and Punish: The Birth of the Prison. Translated by Alan Sheridan, Vintage Books, 1977.

Foucault, Michel. "Préface." De Prison à la révolte by Serge Livrozet. Mercure de France, 1973, pp. 7-14.

Genet, Jean. "Introduction to the First Edition." Soledad Brother: The Prison Letters of George Jackson, Lawrence Hill Books, 1970, pp. 331-339.

Groupe d'Information sur les Prisons. "L'assissinat de George Jackson," "Intolérable » No. 3, Gallimard, 1971. Jackson, George. Soledad Brother: The Prison Letters of George Jackson, 1970.

Koerner, Michelle Renae. "Lines of Escape: Gilles Deleuze's Encounter with George Jackson." Genre 2011, vol. 4, Summer 2011, 160. 
Koerner, Michelle Renae. The Uses of Literature: Gilles Deleuze's American Rhizome. 2010. Duke University, PhD dissertation.

Larson, Doran. "Towards a Prison Poetics." College Literature, vol. 37, no. 3, 2010, pp. 143-166. DOI: https:// doi.org/10.1353/lit.0.0131

Sexton, Jared, "The Social Life of Social Death: On Afro-Pessimism and Black Optimism." Intensions, 2011, no. 5, pp.1-47.

Sharpe, Christina. In the Wake: On Blackness and Being. Duke UP, 2016. DOI: https://doi. org/10.1215/9780822373452

Spillers, Hortense. "Mama's Baby, Papa's Maybe: An American Grammar Book." Diacritics, vol. 17, no 2, 1987, pp. 64-81. DOI: https://doi.org/10.2307/464747

Wilderson, Frank B., III. Red, White and Black: Cinema and the Structure of U.S. Antagonisms. Duke UP, 2010. DOI: https://doi.org/10.1215/9780822391715

How to cite this article: McDougall, T 2019 Left Out: Notes on Absence, Nothingness and the Black Prisoner Theorist. Anthurium, 15(2): 8, 1-10. DOI: https://doi.org/10.33596/anth.391

Published: 23 September 2019

Copyright: ๑ 2019 The Author(s). This is an open-access article distributed under the terms of the Creative Commons Attribution 4.0 International License (CC-BY 4.0), which permits unrestricted use, distribution, and reproduction in any medium, provided the original author and source are credited. See http://creativecommons.org/licenses/by/4.0/. 